these patients and then to send them hack to the slums. A sanatorium for the after-treatment of cases of tubercular bone disease is urgently needed.

Serous labyrinthitis followed operation in 2 out of 27 Schwartze operations, and in 3 out of 52 radical operations.

Cases of purulent labyrinthitis present a well-marked clinical picture: the patient suffers from gidliness and frequently from vomiting; when walking he tends to fall to the diseased side; nystagmus to the sound side is present. In bed the patient lies on the sound side and looks towards the diseased side.

In cases of labyrinthitis associated with meningitis it is porbably best to freely remove the cochlea and so open up the internal meatus, thus providing a copious flow of cerebro-spinal fluid.

Extra-dural abscess was present in 3 of the 32 acute cases and in 8 of the 78 chronic cases : cases in which the dura was exposed by disease but in which no pus was found on further removal of the bone are mot included.

There seems to be a special tendency for the collection of pus between the upper surface of the cerebellum and the lower surface of the tentorium cerehelli in cases of meningitis; is this a "backwater" in the intra-cranial lymph circulation"

In cases of left-sided temporo-sphemoidal abscess ammesiat rerbalis is not invariably present.

In cerebellar cases which do not improve greatly after one abscess has been drained it is important to remember the possibility of a second abseess; in the case recorded a comter-openimg behind the sinus might have led to a favourable result.

The writers wish to express their gratitude to Dr. A. Iogan Turner for his kindness in allowing them to bring before the society the great majority of eases recorded; also to Dr. Shemman and the staff of the Pathological Department of the Royal Intimary for the bacteriological reports.

\title{
THE TEACHING OF OTOLOGY AND LARYNGOLOGY IN ITALY.
}

\author{
By Ferimando Masiet, \\ Ordinary Professor of Laryngology in the University of Naples.
}

'J'He part which Italy has taken in the teaching of laryngology and otology is of not a little importance, and it is with pleasure I shatl try to draw the outlines of its history in my country. 
It is scarcely necessary to say that in this scientific development rhinology is included, as this branch was cultivated with the same vigour both by pure ofologists and pure laryngologists; but above all, it is right to draw attention to the conrageous trials made hy simple private initiative in the first years of life of our speciality. Indeed, before the fondation of any official teaching, rither in Italy or elsewhere, some eminent founders of otology and laryngology delivered lectures on these matters to the medical students or pratirioners who followed the consultations of their private clinics; I may mention Gentile, Venturini, Sapolini, Longo, Labus, (iiampietro as belonging to this period.

According the priority in time to otology, the name and work of a late eminent Italian specialist comes first to my lips: I mean Professor Emilio De Rosid, who since 1866 practised otology in lienoa and wrote a treative on diseases of the car, and in the year 1870 helivered, in Rome, a course of interesting lectures on the subject. The year following he was entrnsted by the Government with the teaching of otology in kome. His desires, however, were mufulfilled; he returned to France, where he had previonsly passed some time, in order to pursue his favourite studies, but he was soon recalled, and a convenient appanage was accorded to the Chair of Rimme. In the year 1881 he was promoted to the degree of Extraordinary Professor of Otolngy, and charged also with the teaching of laryngology. In the year $1879 \mathrm{Dr}$. Carlo Labus was named a privat-docent of laryongology in the University of Pavia, and in the year 188.2 I was entrusted with the teaching of larynmolog in the University of Naples after abont ten years, during which I had delivered private courses on the same matter.

In a few words, the first official chairs in oto laryngology in Italy were that of otology, in Rome, and the other-laryngology -iin Naples. In Rome the teaching soon became mixed-otorhino-laryngology-while that in Naples remained a pure larynwological teaching, and the teaching of otology was confided to Professor (iiampietro till 1891, when it passed into the hands of I'rofessor Cozzolino, and remained separated till at his death March, 1911).

In Italy there are more than eighteen universities, but oto-rhinolaryngology is taught only in eight (Catania, Genoa, Naples, Pavia, Pisa, Rome, Sassari, Turin). 'The high degree of ordinary professor was first obtained by De Rossi, and afterwards by me (Naples), by Ferreri (Rome), who succeeded to Professor De Rossi after 1901, the date of his death, and Gradenigo ('Torino). Masini 
(Genoa), and Grazzi (Pisa), are extraordinary, while the others are ordinary teachers of subjects.

Unhappily, new laws tend to limit this teaching only to official professors, in spite of the efforts and work of the pioneers of the speciality.

Among the eight miversities in which courses of oto-rhinolaryngology are delivered, that of Rome alone possesses clinical wards; the section, directed by Professor Ferreri, is one of the finest in the clinic, and is greatly admired by foreign visitors. ${ }^{1}$

In the others we make use of the out-patients, who apply in considerable numbers to onr consultations. 'The absence of beds, however, deprives us of the opportunity of performing major operations, but the material for demonstration is very large, and we are able to perform all operations of minor importance, as well as oesophagoscopy, tracheoscopy, and bronchoscopy.

It must not be forgotten that in addition to the official teaching, the privat-docents deliver private courses, the prospectuses of which are examined and approved by the medical faculty.

In spite of the official character of the teaching, medical students: are not obliged to follow the course, nor to pass an eximination. Nevertheless several practitioners select oto-rhino-laryngology for their final examination, and if they desire they are permitted to pass a free edamination which gives them no other right than a certificate.

As to the hospital appointments, some privat-docents are directors of special out-patient clinies, and the privilege of teaching the speciality may be acquired by examination, which cousists in at printed dissertation, a lecture, and a practical demonstration. If the candidate can prodnce a sufficient number of publications the dissertation is not required (the commission is made up of fire professors), and they are named "legally qualified privatdocents."

The length of the teaching course is from November to June; short vacancies are accorded at Christmas, Easter, and carnival time. The courses consist of lectures delivered three times a week for an hour, together with a practical demonstration.

As far as I an concerned, I confide to my assistants the teaching. of the technique, the demonstration of anatomical and microscopical specimens, and I deliver the theoretical lectures, and the illustration of clinical cases as they come under my observation. Operations (those permitted upon out-patients) are daily performed before and after the lecture.

1 Recently a clinic, with twenty-five beds, is founded in Catania. 
The Roman clinic, however, is in much better condition, as it possesses several beds, wards for children, for segregation of patients, operating rooms, a room for radiography, a complete laboratory, wards for out-patients, and the administration of the hospital gives it considerable help and encouragement.

In the other seven universities, as has already been pointed ont, the conditions are quite different, and perhaps even worse than those here in Naples. Nevertheless the scientific production in Italy is a very large one-much larger than appears from reports of the foreign papers.

The advancement of our speciality in Italy awaits at present its complete development, which cannot be reached until wards are set apart for our use in common hospitals or university clinics.

\section{SOCIETIES' PROCEEDINGS.}

\section{ROYAL SOCIETY OF MEDICINE-OTOLOGICAL SECTION.}

January 19, 1912.

Dr. W. Muluian, President of the Sectim, in the chair.

\section{Discussion on Factors which conduce to Success in the Treat- ment of Otogenic Brain Abscess.}

I.-Sir V. HorsuEY drew attention, first of all, to the fact that very "fften a case of otitis media, especially if it has been treated by the mastoid operation, is regardel as being well when it is not really well. Regarding diagnosis, he believed that by blood-counts and opsonic tests the occurrence of abscess or meningitis could be anticipated. Stress was laid upon regular, careful neurological examination and upon more frequent bone operation.

The fundamental difficulty lay in differentiating between abscess and meningitis. For this task four or five cardinal symptoms were of value. First of all, the state of the pulse was of value; in meningitis its rate and force exhibited an irregularity not found in uncomplicated abscess. This was due to the involvement of the vagus roots in meningitis. Next, with reference to temperature, in uncomplicated brain abscess he considered low temperature to be an essential characteristic. The temperature might also prove a guide as to the locality of the abscess. The heat-regulating centres are in the Rolandic area, probably in the precentral gyrus, and if the abscess is situated in the coronal plane through he Rolandic area, the temperature will rise on the opposite side of the 